\title{
CHARACTERIZATION OF TWO BENCHMARK SOILS OF CONTRASTING PARENT MATERIALS IN ABIA STATE, SOUTHEASTERN NIGERIA
}

\author{
I. A. CHIKEZIE, H. ESWARAN, D.O. ASAWALAM *AND A. O. ANO
}

(Received 22 November 2007; Revision Accepted 11, September 2009)

\begin{abstract}
Detailed characterization of two important agricultural soils of contrasting parent materials, found in southeastern Nigeria was carried out. The Amakama soil formed over Coastal Plain Sands has a deep, well drained profile greater than $240 \mathrm{~cm}$ deep. The soil texture varies from loamy sand in the surface layer to sandy clay loam down the profile. The Ibeku soil formed over Bende-Ameki (clay shale) formation has a deep profile that is gravelly in the upper $60 \mathrm{~cm}$ and clayey in the lower horizons. Bulk density on oven dry basis ranged from 1.3 to $1.66 \mathrm{~g} \mathrm{~cm}^{-3}$ in the Ibeku soil and from 1.43 to $1.52 \mathrm{~g} \mathrm{~cm}^{-3}$ in the Amakama soil. Water content at $33 \mathrm{kPa}$ ranged from 13.7 to 14.9 in the Amakama soil and from 27.8 to 48.4 in the Ibeku soil. Chemically, the Amakama soil is deficient in basic cations with aluminum saturation being greater than $83 \%$. The soils are very acidic $(\mathrm{pH} 4.5-4.9)$ and low in organic carbon, total nitrogen and available phosphorus. In contrast, the Ibeku soil has high levels of calcium, sum of basic cations that range from 9.2 to $23.5 \mathrm{cmol}(+) \mathrm{kg}^{-1}$ and aluminum saturation of $25-40 \%$. Total nitrogen and organic carbon are medium and available phosphorus is low in this soil. The mineralogy of clay sized particles showed a dominance of kaolinite in both soils with some quantities of montmorillonite that increased down the profile. In the Ibeku soil, the mineralogy of coarse silt fractions showed that goethite and quartz were the dominant minerals in upper horizons $(<1$ $\mathrm{m}$ ) while potassium feldspar and goethite dominated the lower horizons. Amakama soil was classified as Fine loamy, siliceous, isohyperthermic, Rhodic Haplustox while Ajata -lbeku soil was classified as very fine, kaolinitic, isohyperthermic, Aquertic Paleustalf.
\end{abstract}

KEY WORDS: Benchmark soil, Mineralogy, Morphology, Soil properties.

\section{INTRODUCTION}

With a goal of self sufficiency, the Federal Republic of Nigeria has initiated several projects such as the National Special Project on Food Security, presidential task force on cassava and rice production etc. Management technologies to backstop these projects require knowledge of the soils and specifically their response to management. A soil map of Nigeria at a scale of 1: $1,000,000$ was published in 1985. At this reconnaissance scale, fifty-eight soil groups were identified. There is a need for detailed studies of the soils to provide data on which informed decision on choice of site, for developmental projects will be based. Information obtained through detailed survey and soil characterization is vital for land use planning and soil management. The ongoing soil correlation study seeks to investigate the extent and distribution of the important agricultural soils of the country and to fully characterize them. Two benchmark soils formed from contrasting parent materials in Abia State, Nigeria were investigated for this study. Parent material determines soil texture (Young 1976), influences soil drainage and kind of clay as well as $\mathrm{K}$ and $\mathrm{P}$ content of soils and also determines soil properties like colour, structure and reaction
(Faniran and Areola, 1978). Significant relationship between parent material and soil texture, soil reaction, total exchangeable bases, total acidity, soil depth, colour, profile drainage and gravel content have been reported (Akamigbo and Asadu 1983). The soils studied represent the most important agricultural soils of the state. Natural resources, including soils cannot be properly managed without proper understanding of their characteristics (Idoga et al, 2005). Detailed information on soils of the study area is scarce, yet the need to generate soil data to improve agricultural production exists. Such detailed information on soil that should guide agricultural use and management of soil resource is not readily available to farmers; where it exists, it is of limited significance to farmers (Olatunji, 2007). The objective of this study was to characterize in detail, the soils that were referred to as Amakama and Bende soil series in terms of morphological, physical, chemical and mineralogical properties with the view to augment the national database of soil resources. Information of this nature are the prerequisites for better soil management.

\section{MATERIALS AND METHODS}

\section{Study Location}

The study area is located in Abia State,

I. A. Chikezie, Federal Department of Agricultural Land Resources, Eastern Zonal Station, Umudike, Nigeria.

H. Eswaran, World Soil Resources, USDA Natural Resources Conservation Service, Washington, DC. 20250, USA

D.O. Asawalam * College of Crop and Soil Sciences, Michael Okpara University of Agriculture, Umudike, PMB

7267, Umuahia, Abia State, Nigeria.

A. O. Ano, National Root Crops Research Institute, Umudike, Nigeria . 
southeastern Nigeria. Abia State is located at between latitude $4^{\circ} 7$ 'and $6^{\circ} 30 \mathrm{~N}$ and longitude $7^{\circ}$ and $8^{\circ} \mathrm{E}$ in the rainforest agro-ecological zone. The climate is humid tropical with distinct wet season (April to October) and dry season (November to March). Annual rainfall in the area ranges from $1750 \mathrm{~mm}$ to $3000 \mathrm{~mm}$ with peaks in July and September. Average temperature ranges between $27^{\circ} \mathrm{C}$ and $35^{\circ} \mathrm{C}$.

\section{Field Study and Description}

Sites for detailed profile description were selected by staff of the Federal department of Agricultural Land resources from areas previously mapped as Amakama series and Bende series on the basis of profile characteristics and parent material. Profile pits were located at Amakama (Lat. $5^{\circ} 26^{\prime} 40^{\prime \prime} \mathrm{N}$ and Log. $7^{\circ} 28^{\prime} 49^{\prime \prime}$ E) and Ajata-lbeku (Lat. $5^{\circ} 32^{\prime}$ '51" $\mathrm{N}$ and Log. $7^{\circ} 33^{\prime} 34^{\prime \prime} \mathrm{E}$ ) on fallow plots that have not been cropped for at least three years. Whereas the Amakama soil is formed on the Coastal Plain Sands geologic formation, the lbeku soil is formed on Bende Ameki Clay Shale Group. The Coastal Plain Sands, also known as the Benin Formation, is the largest geologic formation in eastern Nigeria. It underlies the area south of Umuahia where Amakama is situated, extending to Aba and beyond to the mainland areas of Rivers and Akwa Ibom states. The Bende-Ameki Shale Group on the other hand, underlies a relatively narrow strip of land north of Umuahia and the entire old Bende extending westwards and joins the Nanka sands Formation near Orlu in Imo State. Both the Coastal Plain Sands and the Bende - Ameki Formation are dominated by plains under $200 \mathrm{~m}$ above sea level. Topography is nearly flat at Amakama where the first profile pit was cited on Coastal Plain Sand. At Ajata - Ibeku where the second soil profile was located, the landscape is highly dissected with deeply incised valleys due to differential erosion of the sandstone and shale that make up the Bende-Ameki Formation.

The pedons were described and sampled according to the established procedures of the USDA Natural Resources Conservation Service (NRCS) guidelines for profile description (Soil Survey Staff, 2002). Soil samples collected from the two profiles were air dried, sieved through a 2-mm sieve and taken to the National Soil Survey Laboratory in Lincoln, Nebraska for detailed laboratory analysis of physical, chemical and mineralogical properties.

\section{Laboratory Procedures}

Particle size analysis was carried out by the hydrometer method (Gee and Bauder, 1986) using sodium hexametaphosphate (calgon) as dispersant. Soil $\mathrm{pH}$ was determined in water at a soil : liquid ratio of $1: 1$ on a combined glass electrode digital $\mathrm{pH}$ meter (Thomas, 1996). Exchangeable cations were extracted with neutral normal ammonium acetate. Exchangeable potassium and sodium in the extract were determined using a flame photometer while exchangeable calcium and Magnesium were determined using atomic absorption spectrophotometer. Organic carbon was determined by the wet oxidation method (Nelson and
Sommers, 1996). Total nitrogen was determined by the kjeldahl digestion and distillation method (Bremner, 1996). Available phosphorus was determined by Bray 2 extract by the method of Olsen and Sommer, 1982. The mineralogy of the fractions was characterized by X-ray diffraction techniques (Whittig and Allardice, 1986).

\section{RESULTS AND DISCUSSIONS}

\section{Morphological Characteristics}

Table 1 gives the morphological data of the representative pedons. The Amakama pedon is formed from a uniform parent material as revealed by the almost uniform distribution of the fine sand fraction (table 2). The profile is very deep $(>240 \mathrm{~cm})$ and well drained. The hue is $2.5 \mathrm{YR}$ throughout the profile depth. It has no root or water restrictive layer within the profile depth. It has an ochric epipedon that is about $27 \mathrm{~cm}$ thick with a texture of loamy sand to sandy loam, structure of weak fine granular to weak medium subangular blocky, a moist friable consistence and a gradual smooth boundary between the $A$ and $B$ horizons. The B-horizon is dominated by an oxic horizon between the $27 \mathrm{~cm}$ and $240 \mathrm{~cm}$ depth. There is also a preponderance of pedovites (spherical soil bodies of one to three centimeters diameter) throughout this horizon. The origin and occurrence of pedovites is not evident but they are more frequent in soils at an advanced stage of soil formation. Though they are distinct and are easily separated from the general soil mass, they do not show any kind of cementation or have higher concentrations of free iron. The horizon has a texture of sandy clay loam to sandy clay, a weak angular blocky to moderate fine subangular blocky structure and moist friable consistence.

The lbeku pedon is a layered soil formed on transported sediments of sandstone origin occurring over a material weathered in place from clay shale, which generally underlies the area. The sandy mantle has a hue of 10YR to 5YR (moist), a texture of gravelly sandy loam to gravelly sandy clay, a structure of weak fine crumb to moderate medium subangular blocky, a moist friable consistence, common petroplinthite nodules (lateritic gravel) and a clear and smooth boundary with the underlying horizon. This mantle has an ochric epipedon that is about $28 \mathrm{~cm}$ thick and a Bhorizon that has patchy clay films on faces of peds. The underlying finer textured material on the other hand, which is developed from clay shale residuum, has a hue of 10YR throughout, a texture of sandy clay to clay, a structure of moderate medium subangular blocky to moderate coarse wedge and a moist firm and sticky and plastic wet consistence. The good structural development may have been influenced by the high clay content of the soil. It has patchy clay films on ped faces and slickenside between $80 \mathrm{~cm}$ to $190 \mathrm{~cm}$ depth. Clay films (cutans) are indicative of illuvial process (Kparmwang et al, 2004). In addition, the profile is mottled from the $60 \mathrm{~cm}$ depth indicating poor drainage conditions. It has an argillic horizon between depths of $60 \mathrm{~cm}$ and $164 \mathrm{~cm}$. 
Table 1: Morphological Properties of the representative pedons.

\begin{tabular}{|c|c|c|c|c|c|c|c|c|}
\hline Horizon & Depth & $\begin{array}{l}\text { Moist } \\
\text { colour }\end{array}$ & Texture & Structure+ & $\begin{array}{l}\text { Clay } \\
\text { skin }\end{array}$ & $\begin{array}{c}\text { Consis- } \\
\text { tence } \\
++\end{array}$ & Inclusions & $\begin{array}{c}\text { Boundary } \\
+++\end{array}$ \\
\hline \multicolumn{9}{|c|}{ Amakama soil } \\
\hline Ap1 & $0-13$ & 2.5YR2.5/2 & LS & $1 \mathrm{fg}$ & - & mfri & $\begin{array}{c}\text { Coated quartz } \\
\text { grains }\end{array}$ & Gs \\
\hline Ap2 & $13-27$ & 2.5YR2.5/2 & $\mathrm{SL}$ & $1 \mathrm{msbk}$ & - & mfri & pedovites & gs \\
\hline Bo1 & $27-63$ & 2.5YR3/2 & SCL & $1 \mathrm{msbk}$ & - & mfri & pedovites & gs \\
\hline Bo2 & 63-99 & 2.5YR3/6 & SCL & $1 \mathrm{msbk}$ & - & mfri & pedovites & gs \\
\hline Bo3 & $99-127$ & $2.5 \mathrm{YR} 4 / 6$ & SCL & $1 \mathrm{msbk}$ & - & mfri & pedovites & gs \\
\hline Bo4 & $127-159$ & $2.5 \mathrm{YR} 4 / 6$ & SC & $2 \mathrm{fsbk}$ & - & mfri & pedovites & gs \\
\hline Bo5 & $159-210$ & 2.5YR4/6 & SC & $2 \mathrm{fsbk}$ & - & mfri & pedovites & gs \\
\hline Bo6 & $210-240$ & 2.5YR4/6 & SC & \multicolumn{3}{|c|}{ Ibeku soil } & pedovites & gs \\
\hline Ap1 & $0-9$ & 10YR3/4 & GSL & $1 \mathrm{fc}$ & None & Mfri & $\begin{array}{l}\text { Petroplinthic } \\
\text { nodules }\end{array}$ & Gs \\
\hline Ap2 & $9-28$ & $5 Y R 4 / 3$ & GSCL & $2 \mathrm{msbk}$ & None & Mfri & -do- & Gs \\
\hline $\mathrm{Bt}$ & $28-60$ & 5YR4/6 & GSC & $2 \mathrm{msbk}$ & $\underset{n}{\text { Commo }}$ & Mfri & -do- & Cs \\
\hline 2Btg & $60-80$ & 10YR4/1 & SC & $2 \mathrm{msbk}$ & $\begin{array}{c}\text { Commo } \\
\mathrm{n}\end{array}$ & Mfirm & $\begin{array}{c}\text { Common } \\
\text { slickenside }\end{array}$ & Gs \\
\hline 2Bssg1 & $80-101$ & 10YR5/2 & C & $2 \mathrm{cw}$ & Many & Mfirm & $\begin{array}{l}\text { Large common } \\
\text { slickensides }\end{array}$ & Ds \\
\hline 2Bssg2 & $101-128$ & 10YR5/2 & C & $2 \mathrm{cw}$ & Many & Mfirm & -do- & Gs \\
\hline 2Bssg3 & $128-164$ & 10YR5/2 & C & $2 \mathrm{cw}$ & - & - & -do- & Gs \\
\hline 2Bgss & $164-190$ & 10YR5/2 & $\mathrm{C}$ & $2 \mathrm{cw}$ & - & - & -do- & \\
\hline
\end{tabular}

+ Structure - 1 = weak, 2 = moderate, $3=$ strong, $f=$ fine, $m=$ medium, $c=$ coarse, $g=$ granular, $\mathrm{cr}=$ crumb, sbk = subangular blocky, agb = angular blocky, ma = massive .

++ Consistence $-\mathrm{m}=$ moist, $\mathrm{d}=$ dry, $\mathrm{fi}=$ firm, $\mathrm{fr}=$ friable, $\mathrm{h}=$ hard, $\mathrm{s}=$ sticky, $\mathrm{ns}=$ non-sticky. +++ Boundary - $c$ = clear, $w=$ wavy, $a=$ abrupt, $d=$ diffuse, $s=$ smooth, $w=$ wavy, $g=$ gradual.

Table 2: Particle Size Distribution of the soils

\begin{tabular}{|c|c|c|c|c|c|c|c|c|c|}
\hline Horizon & $\begin{array}{c}\text { Depth } \\
(\mathrm{cm})\end{array}$ & VCS & CS & MS & FS & VFS & CSi & $\mathrm{FSi}$ & Clay \\
\hline & & & & \multicolumn{2}{|c|}{ Amakama soil } & & & & \\
\hline Ap1 & $0-13$ & 0.3 & 12.5 & 29.7 & 28.2 & 5.1 & 2.3 & 1.3 & 20.6 \\
\hline Ap2 & $13-27$ & 0.4 & 10.8 & 31.8 & 24.7 & 5.0 & 1.9 & 1.2 & 24.2 \\
\hline Bo1 & $27-63$ & 0.9 & 11.2 & 28.9 & 23.0 & 4.1 & 1.7 & 2.0 & 28.2 \\
\hline Bo2 & $63-99$ & 0.9 & 11.8 & 25.1 & 22.3 & 3.8 & 3.2 & 1.6 & 31.3 \\
\hline Bo3 & $99-127$ & 0.9 & 13.5 & 24.9 & 21.2 & 4.5 & 2.5 & 1.2 & 31.3 \\
\hline Bo4 & $127-159$ & 1.0 & 12.3 & 25.5 & 19.7 & $\mathrm{Tr}$ & 6.9 & 1.8 & 32.8 \\
\hline Bo5 & $159-210$ & 1.1 & 12.1 & 25.1 & 21.7 & 4.3 & 1.4 & 1.8 & 32.5 \\
\hline \multirow[t]{2}{*}{ Bo6 } & $210-240$ & 2.0 & 12.8 & 24.0 & 21.4 & 3.1 & 2.9 & 1.9 & 31.9 \\
\hline & & & & \multicolumn{2}{|c|}{ lbeku soil } & & & & \\
\hline Ap1 & $0-9$ & 5.0 & 8.0 & 3.7 & 4.0 & 13.4 & 12.8 & 13.9 & 39.2 \\
\hline Ap2 & $9-28$ & 5.1 & 7.9 & 3.9 & 3.1 & 11.7 & 9.7 & 13.1 & 45.5 \\
\hline $\mathrm{Bt}$ & $28-60$ & 1.8 & 1.7 & 1.1 & 1.3 & 4.4 & 5.2 & 9.6 & 74.9 \\
\hline 2Btg & $60-80$ & 0.2 & 0.7 & 0.9 & 1.4 & 3.0 & 4.4 & 7.7 & 81.7 \\
\hline 2Bssg1 & 80-101 & 0.2 & 0.7 & 1.1 & 2.4 & 4.0 & 3.9 & 7.2 & 80.5 \\
\hline 2Bssg2 & $101-128$ & 0.5 & 2.4 & 2.9 & 2.8 & 4.1 & 4.9 & 4.3 & 78.1 \\
\hline 2Bssg3 & $128-164$ & $\mathrm{Tr}$ & 0.4 & 1.2 & 3.1 & 3.4 & 4.4 & 4.3 & 83.2 \\
\hline 2Bgss & $164-190$ & -- & 0.1 & 0.8 & 2.7 & 5.0 & 9.6 & 7.7 & 74.1 \\
\hline
\end{tabular}

\section{Physical Properties}

\section{Particle size distribution}

The particle size distribution of the soils (table 2) shows that total sand constitutes $63-76 \%$ of the mineral fractions in Amakama soil with fine sand and medium sand fractions dominating. Clay fractions vary from $21-33 \%$ while silt content is less than $9 \%$. Low clay content of surface horizons could be due to sorting of soil material by biological and /or agricultural activities, clay migration or surface erosion by runoff or a combination of these (Malgwi et al, 2000; Ojanuga,
1975). The dominance of sand in this soil reflects the parent material of the soil, which is coastal plain sand.

The soil of Ibeku is very gravelly especially in the upper $60 \mathrm{~cm}$ of the profile. Gravels (iron/manganese concretions) in the profile right from the soil surface indicate that plinthization may be involved in the pedogenic process of the area (Fasina et al, ------ ; Kparmwang et al, 2004). Clay content (39 - 83\%) increased with depth. The texture of this soil is clay loam in the upper $0-9 \mathrm{~cm}$ topsoil and clayey in the other horizons to a depth of $190 \mathrm{~cm}$. According to Idoga and 
Azagaku, 2005, increase in clay with depth may be the result of eluviation - illuviation processes as well as contributions of the underlying geology through weathering. The clayey nature of this soil suggests the capacity to hold more water and nutrients than Amakama soil with sandy clay loam texture.

\section{Water content and Bulk density}

Water content at field capacity $(33 \mathrm{Kpa})$ ranged from 13 - 16 in Amakama soil and 28 - 54 in Ibeku soil. This result shows that Ibeku soil retains more water than Amakama soil. This higher moisture content in Ibeku soil is due to its higher clay content. At wilting point (1500Kpa), Ibeku soil still has more moisture content (19 - 33) than Amakama soil $(9-11)$. Bulk density varies from $1.31-1.52 \mathrm{~g} \mathrm{~cm}^{-3}$ in Amakama soil and from $1.37-$ $1.68 \mathrm{~g} \mathrm{~cm}^{-3}$ in Ibeku soil. The higher bulk density in Ibeku soil relative to Amakama soil may be explained by the gravelly nature of the Ibeku soil. Within the Ibeku soil profile, possibility of migrating clay filling up the pore spaces in the supposedly well structured Bt horizon may account for the high bulk density values in the subsurface horizons (Idoga and Azagaku, 2005).

Table 3: Bulk Density and Water content of the soils.

\begin{tabular}{|c|c|c|c|c|c|}
\hline Horizon & $\begin{array}{l}\text { Depth } \\
\text { (cm) }\end{array}$ & $\begin{array}{c}\mathrm{BD} \\
\mathrm{gcm}^{-3}\end{array}$ & $\begin{array}{c}\text { Water content } \\
33 \mathrm{kpa}\end{array}$ & $1500 \mathrm{kpa}$ & $\begin{array}{c}\text { Cole } \\
\mathrm{cm} \mathrm{cm}^{-3}\end{array}$ \\
\hline & \multicolumn{5}{|c|}{ Amakama soil } \\
\hline Ap1 & $0-13$ & 1.43 & 13.7 & 8.6 & 0.017 \\
\hline Ap2 & $13-27$ & 1.31 & 13.4 & 9.8 & 0.005 \\
\hline Bo1 & $27-63$ & 1.39 & 14.5 & 10.3 & 0.007 \\
\hline Bo2 & $63-99$ & 1.45 & 15.0 & 10.7 & 0.009 \\
\hline Bo3 & $99-127$ & 1.48 & 15.0 & 10.6 & 0.002 \\
\hline Bo4 & $127-159$ & 1.48 & 15.4 & 10.8 & 0.012 \\
\hline Bo5 & $159-210$ & 1.51 & 15.5 & 11.4 & 0.009 \\
\hline \multirow[t]{2}{*}{ Bo6 } & $210-240$ & 1.52 & 14.9 & 10.9 & 0.014 \\
\hline & & \multicolumn{2}{|c|}{ lbeku soil } & & \\
\hline Ap1 & $0-9$ & & & 19.2 & \\
\hline Ap2 & $9-28$ & 1.37 & 27.8 & 20.3 & 0.010 \\
\hline $\mathrm{Bt}$ & $28-60$ & 1.54 & 40.2 & 28.6 & 0.059 \\
\hline 2Btg & $60-80$ & 1.54 & 48.1 & 29.6 & 0.127 \\
\hline 2Bssg1 & $80-101$ & 1.53 & 43.1 & 29.1 & 0.098 \\
\hline 2Bssg2 & $101-128$ & 1.62 & 45.9 & 31.3 & 0.108 \\
\hline 2Bssg3 & $128-164$ & 1.68 & 53.8 & 33.1 & 0.126 \\
\hline 2Bgss & $164-190$ & 1.66 & 48.4 & 32.2 & 0.069 \\
\hline
\end{tabular}

\section{Chemical Properties}

Some chemical properties of the representative profiles are shown in table 4. The soil reaction indicated strong to extremely acid conditions. The low $\mathrm{pH}$ of these soils is attributed to heavy leaching promoted by the very high rainfall in the area. Acidity (low pH) of the soils may also be due to the effect of cultivation, erosion and leaching of nutrients or a combination of these.

Table 4: Chemical properties of the soils

\begin{tabular}{|c|c|c|c|c|c|c|c|c|c|}
\hline \multirow[t]{2}{*}{ Horizon } & $\begin{array}{l}\text { Depth } \\
\text { (cm) }\end{array}$ & $\begin{array}{c}\mathrm{pH} \\
\left(\mathrm{H}_{2} \mathrm{O}\right)\end{array}$ & TEB & $\begin{array}{l}\text { EA } \\
\text { I(+)k }\end{array}$ & ECEC & \multirow[t]{2}{*}{$\begin{array}{c}\mathrm{P} \\
\mathrm{mg} / \mathrm{kg}\end{array}$} & \multicolumn{2}{|c|}{ TN } & \multirow[t]{2}{*}{$\begin{array}{l}\text { Al } \\
\text { Sat }\end{array}$} \\
\hline & & & & \multicolumn{2}{|c|}{ Amakama soil } & & & & \\
\hline Ap1 & $0-13$ & 4.5 & 0.5 & 11.1 & 11.6 & 80.9 & 0.107 & 2.07 & 83 \\
\hline Ap2 & $13-27$ & 4.6 & 0.1 & 9.8 & 9.9 & 5.1 & 0.086 & 1.43 & 95 \\
\hline Bo1 & $27-63$ & 4.6 & $\mathrm{Tr}$ & 6.6 & 6.6 & 2.8 & 0.042 & 0.57 & - \\
\hline Bo2 & $63-99$ & 4.7 & $\mathrm{Tr}$ & 6.5 & 6.5 & 1.7 & 0.026 & 0.43 & - \\
\hline Bo3 & $99-127$ & 4.7 & 0.1 & 5.1 & 5.2 & 1.2 & 0.023 & 0.37 & 92 \\
\hline Bo4 & $127-159$ & 4.8 & $\mathrm{Tr}$ & 4.7 & 4.7 & $\mathrm{Tr}$ & 0.011 & 0.25 & - \\
\hline Bo5 & $159-210$ & 4.9 & $\operatorname{Tr}$ & 3.9 & 3.9 & $\operatorname{Tr}$ & 0.013 & 0.23 & - \\
\hline \multirow[t]{2}{*}{ Bo6 } & $210-240$ & 4.9 & $\operatorname{tr}$ & 4.3 & 4.3 & $\operatorname{Tr}$ & 0.023 & 0.17 & - \\
\hline & & & & \multicolumn{2}{|c|}{ Ibeku soil } & & & & \\
\hline Ap1 & $0-9$ & 5.0 & 9.2 & 24.4 & 33.6 & 4.4 & 0.311 & 3.39 & 25 \\
\hline Ap2 & $9-28$ & 4.8 & 4.9 & 24.5 & 29.4 & 4.2 & 0.189 & 2.26 & 58 \\
\hline $\mathrm{Bt}$ & $28-60$ & 4.8 & 3.7 & 22.8 & 26.5 & 0.2 & 0.096 & 0.98 & 74 \\
\hline $2 \mathrm{Btg}$ & $60-80$ & 4.7 & 4.8 & 24.6 & 29.4 & 0.1 & 0.063 & 0.57 & 78 \\
\hline 2Bssg1 & $80-101$ & 4.7 & 5.0 & 25.7 & 30.7 & 0.2 & 0.051 & 0.41 & 81 \\
\hline 2Bssg2 & $101-128$ & 4.5 & 9.5 & 29.2 & 38.7 & $\operatorname{Tr}$ & 0.031 & 0.29 & 66 \\
\hline 2Bssg3 & $128-164$ & 3.8 & 17.3 & 29.4 & 46.7 & $\mathrm{Tr}$ & 0.037 & 0.25 & 40 \\
\hline 2Bgss & $164-190$ & 4.2 & 23.5 & 22.9 & 46.4 & $\mathrm{Tr}$ & 0.018 & 0.27 & 9 \\
\hline
\end{tabular}


Total Exchangeable bases and Cation exchange
capacity
Total exchangeable bases (TEB) are low in Ibeku soil and in traces in Amakama soil. This confirms that Amakama soil is strongly weathered and excessively leached. The effective cation exchange capacity of the soils is generally low and dominated by exchangeable acidity. The very low to low effective cation exchange capacity of these soils indicates low capacity of these soils to retain nutrient elements. Low cation exchange capacity which is a consequence of low clay and organic matter content, renders soils unsuitable for intensive agriculture (Kparmwang et al, 2004). The high level of exchangeable acidity and high aluminum saturation of these soils indicate the need for management practices to reduce the effects of acidity and possibly aluminum toxicity.

\section{Organic carbon and other Elements}

The top $30 \mathrm{~cm}$ of Amakama soil has medium levels of organic carbon contents while the Ibeku soil has high organic matter. In both soils, the values decreased with depth. The environment of eastern Nigeria is characterized by high temperature and relative humidity conditions that favour rapid decomposition and mineralization of organic matter. This could explain the low levels of organic carbon in the soils. The soils are low in nitrogen. The lower horizons of both soils are deficient in phosphorus while the upper horizons have low values except the topsoil of Amakama. The low levels of nitrogen and phosphorus in the soils may be due to intensive cropping practices without measures to build up soil nutrient reserves.

\section{MINERALOGY \\ Clay mineralogy}

The mineralogy of clay particles $(<0.002 \mathrm{~mm})$ is summarized in table 5 . The results show that Amakama soil has mixed mineralogy dominated by kaolinite. Small quantities of goethite, gibbsite and haematite are also present. The mineralogy is similar in all the pedogenic horizons. In the Ibeku soil, the mineralogy is kaolinitic in the upper $100 \mathrm{~cm}$ of the profile and mixed clay mineralogy at the lower depths. The mineralogy of this soil is also dominated by kaolinite but has detectable quantities of montmorillonite, and small quantities of goethite and gibbsite. At the depth of $164-190 \mathrm{~cm}$, plagioclase feldspar was also present. The dominance of kaolinite in these soils agrees with previous studies by Jungerius and Levelt (1964) and lgwe et al (1999) on the soils of eastern Nigeria. The presence of montmorillonite and plagioclase feldspar in Ibeku soil shows that the soil contains some weatherable minerals. The presence of kaolinite suggests that the soils are at an advanced stage of weathering. The high rainfall and temperatures in this agroecological zone are favorable to intensive weathering and rapid leaching. Jungerius and Levelt (1964) suggested that the mineralogy of the soils of eastern Nigeria has been inherited from the bedrock or sediment. This is true especially of Amakama soil derived from coastal plain sands. They also reported that montmorillonite is a significant component of several soils derived from the river Niger deposits and the Imo clay shale. The parent material of Ibeku soil is Bende-Amake (clay shale) formation. The soils have hydromorphic properties in most areas and support reasonable rice production for which Bende is famous. Poor internal drainage conditions retard the alteration of these minerals and may account for the presence of some 2 : 1 clay minerals in lbeku soil. Based on the mineralogical composition, the soil of Amakama can be said to be more intensively weathered than the Ibeku soil.

Table 5: Mineralogy of clay particles (<0.002 mm).

\begin{tabular}{|c|c|c|c|c|c|c|c|c|c|}
\hline \multirow{3}{*}{$\begin{array}{l}\text { Horizon } \\
\text { Ap1 }\end{array}$} & \multirow[t]{2}{*}{$\begin{array}{l}\text { Depth } \\
(\mathrm{cm})\end{array}$} & \multicolumn{4}{|c|}{$\begin{array}{c}\text { Xray } \\
----- \\
\end{array}$} & \multicolumn{3}{|c|}{$\begin{array}{c}\text { TGA } \\
------\end{array}$} & \multirow[t]{2}{*}{$\begin{array}{l}\text { Interpre } \\
\text {-tation }\end{array}$} \\
\hline & & & & Amak & a soil & & & & \\
\hline & $0-13$ & KK 4 & Gl 1 & HE 1 & GE 1 & KK 69 & GI 2 & GE 18 & CMIX \\
\hline Bo1 & $27-63$ & KK 4 & $\mathrm{HE} 1$ & GE 1 & $\mathrm{Gl} 1$ & KK 60 & GE 15 & $\mathrm{Gl} 2$ & CMIX \\
\hline Bo2 & $63-99$ & KK 4 & GE 1 & GI 1 & HE 1 & KK 62 & GE 13 & $\mathrm{GI} 2$ & CMIX \\
\hline Bo4 & $127-159$ & KK 4 & HE 1 & GE 1 & Gl 1 & KK62 & $\mathrm{Gl} 2$ & & CMIX \\
\hline \multirow[t]{2}{*}{ Bo6 } & $210-240$ & KK 4 & HE 1 & $\mathrm{GI} 1$ & GE 1 & KK 56 & GE 9 & $\mathrm{Gl} 2$ & CMIX \\
\hline & & & & \multicolumn{2}{|c|}{ Ibeku soil } & & & & \\
\hline Ap1 & $0-9$ & KK 5 & MT 2 & QZ1 & GE 1 & KK 44 & GE 22 & $\mathrm{Gl} 2$ & KAOL \\
\hline $\mathrm{Bt}$ & $28-60$ & KK 5 & MT 2 & GE 1 & & KK 55 & & & KAOL \\
\hline $2 \mathrm{Btg}$ & $60-80$ & KK 5 & MT 2 & GE 1 & & KK 55 & GE 50 & GI 1 & KAOL \\
\hline 2Bssg2 & $101-128$ & KK 5 & MT 3 & GE 1 & & KK 51 & & & CMIX \\
\hline 2Bgss & $164-190$ & KK 5 & MT 4 & GE 1 & QZ 1 & KK 39 & GI 1 & & CMIX \\
\hline
\end{tabular}

\section{Sand - Silt mineralogy}

Optical grain count of the fine sand $(0.1-0.25$ $\mathrm{mm}$ ) fraction (table 6) showed that Amakama soil is dominated by quartz with trace quantities of goethite, sphalerite, tourmaline, pyroxene, opaques and zircon. Constancy of particle size distribution of resistant minerals like zircon has been used to identify lithologic uniformity (Barshard, 1964) as the minerals do not undergo significant change during the course of soil formation. The clay content is relatively constant with depth (Table 2), an indication of little or no clay movement in the profile, suggesting a high order of stability in the clay distribution. The absence of primary weatherable mineral and a low charge are diagnostic of an oxic horizon (Soil Survey Staff, 1999) while presence of resistant minerals like quartz and zircon in fine silt 
fraction indicate that the soil has reached advanced stage of weathering. Optical grain count of the coarse silt $(0.02-0.05 \mathrm{~mm})$ fraction of the Ibeku soil (table 6) showed the presence of goethite, potassium feldspar, and quartz with trace quantities of biotite, calcite, hornblende, muscovite, opaques, rutile and zircon. The presence of weatherable minerals in this soil confirms that this soil is less intensively weathered than Amakama soil.

Table 6: Mineralogy for coarse silt fractions $(0.02-0.05 \mathrm{~mm})$

\begin{tabular}{|c|c|c|c|c|c|c|c|c|c|}
\hline \multirow[t]{2}{*}{ Horizon } & \multirow[t]{2}{*}{$\begin{array}{c}\text { Depth } \\
(\mathrm{cm})\end{array}$} & \multirow{2}{*}{\multicolumn{2}{|c|}{ Fraction }} & \multicolumn{5}{|c|}{ Optical Grain count } & \\
\hline & & & & Amak & a soil & & & & \\
\hline Ap1 & $0-13$ & Fs & QZ 100 & SG tr & $\mathrm{MT}$ tr & ZR tr & & & \\
\hline Bo1 & $27-63$ & Fs & QZ 98 & FE 1 & OP tr & $\mathrm{PR}$ tr & PR tr & TM tr & ZR tr \\
\hline Bo2 & $63-99$ & Fs & QZ 100 & SG tr & TM tr & FE tr & SG tr & $\mathrm{PR}$ tr & $\mathrm{HN} \operatorname{tr}$ \\
\hline Bo4 & $127-159$ & Fs & QZ 99 & ZR tr & FE tr & OP tr & OP tr & & \\
\hline \multirow[t]{2}{*}{ Bo6 } & $210-240$ & Fs & QZ 99 & OP 1 & PR tr & $S G \operatorname{tr}$ & PR tr & $Z R \operatorname{tr}$ & $\mathrm{FE}$ tr \\
\hline & & & & \multicolumn{2}{|c|}{ lbeku soil } & & & TM tr & \\
\hline Ap1 & $0-9$ & $\mathrm{CSi}$ & FE 39 & QZ 35 & FK 20 & PO 5 & & & \\
\hline $\mathrm{Bt}$ & $28-60$ & Csi & FE 63 & QZ 30 & FK 6 & OP 1 & PR 1 & & \\
\hline 2Btg & $60-80$ & Csi & FE 57 & QZ 28 & FK 10 & OP 3 & & & \\
\hline 2Bssg2 & $101-128$ & Csi & FK 48 & FE 38 & QZ 18 & PR 1 & PR 1 & & \\
\hline 2Bgss & $164-190$ & Csi & FK 53 & FE 33 & QZ 12 & OP 1 & CL 1 & & \\
\hline
\end{tabular}

$\mathrm{FE}=$ Iron Oxide (Goethite, $\mathrm{HN}=$ Hornblende, $\mathrm{OP}=$ Opaques, $\mathrm{PR}=$ Pyroxene, $\mathrm{QZ}=$ Quarttz, $\mathrm{SG}=$ Sphalerite, $\mathrm{TM}=$ Tourmaline, $\mathrm{ZR}=$ Zircon, $\mathrm{BT}=$ Biotite, $\mathrm{CL}=$ Chlorite .

\section{CONCLUSION}

We characterized soils previously mapped as Amakama series and Bende series in terms of their morphological, physical, chemical and mineralogical properties. Morphologically, the soils are very deep (> $190 \mathrm{~cm}$ ), with moist hue of 2.5YR (Amakama) and 10YR to $5 \mathrm{YR}$ (Ibeku). Soil structure varies from weak fine granular to moderate medium sub-angular blocky, a moist friable consistence and a gradual smooth boundary. Particle size distribution showed that sand dominated the mineral soil particles in Amakama soil (63 $-76 \%$ ) while clay was the dominant size fraction in the Ibeku soil (39 - 83\%). Water content at both field capacity and permanent wilting point were higher in lbeku soil than Amakama soil and bulk density varied from $1.31-1.68 \mathrm{~g} \mathrm{~cm}^{-3}$. Chemically, the soils are acidic, low in organic matter and mineral nutrient contents. The Amakama soil was particularly deficient of exchangeable basic cations with aluminum saturation of over $90 \%$. The soils were characterized by low effective cation exchange capacity. Clay mineralogy showed mixed clay mineralogy dominated by kaolinite in Amakama soil but koalinitic upper horizon and mixed clay mineralogy in the lbeku soil with detectable quantities of montmorillonite, goethite and gibbsite. Resistant minerals like quartz and zircon were also shown in the sand-silt mineralogy of the soils. Though the soils have supported arable crop production for centuries, the morphological and physical characteristics, chemical composition and mineralogical properties suggest that sustainable crop production on the soils will require very careful management, especially the Amakama soil. Constant inputs of organic and mineral fertilizers will be required to enhance soil fertility and improve crop yield.

\section{REFERENCES}

Akamigbo, F. O. R. and Asadu, C. L. A., 1983. Influence of parent materials on soils of southeastern Nigeria. East African Forestry Journal, 48: 81 91.
Barshad, I., 1964. Chemistry of Soil Development. In: F. E. Beer (Editor). Chemistry of the soil. Raynold Pub. Corp. New York.

Bray,R. H. and L. T. Kurtz, 1945. Determination of total and organic forms of phosphorus in Soils. Soil Science, 59: $39-45$.

Bremner, J. M., 1996. Nitrogen - Total. In: D. L. Sparks (Editor) Pp 1085 - 1122. Methods of Soil Analysis Part 3 - Chemical Methods, SSSA Book Series 5, Madison, Wisconsin, USA.

Faniran, A. and O. Areola 1978. Essentials of Soil Study: with special reference to tropical areas. Heinemann Educational Books Ltd. London.

Fasina, A.S., J.O. Aruleba, F.O. Omolayo, S.O. Omotosho, O.S. Shittu and Okusami, T. A., 2005. Properties and classification of five soils formed on granitic parent material of Humid southwestern Nigeria. Nigerian Journal of Soil Science, 15: $21-29$.

Gee, G. W. and Bauder, J. W., 1986. Particle size analysis. In Arnold Klute (Editor) Pp 383-412. Methods of Soil Analysis, Part 1 - Physical and Mineralogical Methods, SSSA Book Series 5, Madison, Wisconsin, USA.

Idoga, S and Azagaku, D.E., 2005. Characterization and classification of soils of Janta Area, Plateau State of Nigeria. Journal of Soil Science, 15: $116-122$.

Idoga, S., S.O. Abagyeh and Agber, P.I., 2005. Characteristics and classification of crop production potentials of soils of the Aliade plain, Benue State, Nigeria. Journal of Soil Science, 15: $101-110$. 
Igwe, C.A., F. O. R. Akamigbo and Mbagwu, J. S. C.,

1999. Chemical and mineralogical properties of soils in Southestern Nigeria in relation to aggregate stability. Geoderma, 92: 111 - 123.

Jungerius, P. D and T. W.M. Levelt, 1964. Clay mineralogy of soils over sedimentary rocks in Eastern Nigeria. Soil Science, 97: 89 -95.

Kparmwang, T., V.O. Chude and D. Abdullahi 2004. The classification and genesis of benchmark soils of Bauchi State, Nigera. Journal of Soil Science, 14: $30-39$.

Malgwi, W. B., A. G. Ojanuga, V. O. Chude, T. Kparmwang, and B. A. Raji, 2000. Morphological and Physical Properties of some soils of Samaru, Zaria, Nigerian Journal of Soil Research, 1: 58 64.

Ojanuga, A. G. 1975. Morphological, Physical and Chemical characteristics of soils of Ife and Ondo areas. Nigerian Journal of Soil Science, 9: 225 269.

Olatunji, O. O. M., A. O. Ogunkunle and F.O. Tabi, 2007. Influence of parent material and topography on some soil properties in southwestern Nigeria. Nigerian Journal of Soil and Environmental Research, 7: $1-6$.
Nelson, D. W. and L. E. Sommers 1996. Total Carbon, Organic Carbon and Organic Matter. In: D. L. Sparks (Editor) Pp 961 - 1010. Methods of Soil Analysis Part 3 - Chemical Methods, SSSA Book Series 5, Madison, Wisconsin, USA.

Young, A. 1976. Tropical Soils and Soil survey. Cambridge: Cambridge University Press.

Soil Survey Staff 1999. Soil Taxonomy. A basic system of soil classification for making and interpreting soil surveys. $2^{\text {nd }}$ Edition. USDA Agricultural Handbook No. 436

Soil Survey Staff 2002. Field book for describing and sampling soils. VCersion2.0 National soil survey centre, National Resources Conservation service, USDA Lincoln Nebraska.

Thomas, G. W. 1996. Soil pH and Soil Acidity. In: D. L. Sparks (Editor) Pp 475 - 490. Methods of Soil Analysis Part 3 - Chemical Methods, SSSA Book Series 5, Madison, Wisconsin, USA.

Whittig, L. D. and W. R. Allardice, 1986. X - Ray diffraction Techniques. In Arnold Klute (Editor) Pp 331 - 362. Methods of Soil Analysis, Part 1 Physical and Mineralogical Methods, SSSA Book Series 5, Madison, Wisconsin, USA. 